\title{
Genealogy versus Merit? On the Role of Lineage in Ancient Judaism. Introduction
}

\author{
Katell Berthelot \\ Professor, Centre National de la Recherche Scientifique (CNRS), \\ Aix-en-Provence, France \\ katell.berthelot26@gmail.com
}

Concerns about genealogy permeate many ancient and modern societies and groups. Ancestors have to do with the question of one's origins and, more often than not, with one's place in the world. Genealogies have also proved fundamental to some collective ethnic self-definitions. Modern scholarly discussions of ethnicity in the ancient world have emphasized - among other criteria - the importance of shared ancestors, whether imagined or real, to define membership in a group. ${ }^{1}$ Admittedly, in contemporary Western countries, genealogies may be perceived as belonging to the realm of hobbies (as in the case of people attempting to reconstruct their genealogical trees). Especially in the professional realm, the emphasis is on personal training, capacities, and achievements rather than on the identity of one's ancestors. In short, merit or personal worth prevails over lineage. However, DNA tests reflect a new type of fascination with genealogy, buttressed by the scientific aura of genetic studies. Moreover, the impact of genetics on Jewish communities and Jewish studies - in relation to the origins of the Jewish people and the definition of Jewishness - is growing. ${ }^{2}$ On the whole, lineage probably matters for many people in our contemporary world no less than it did for people living in the Greco-Roman world.

Some anthropological studies have emphasized that kinship ties are cultural constructions that cannot be limited to the biological links based on

1 See Hutchinson and Smith, Ethnicity; Malkin and Müller, "Vingt ans d'ethnicité," 25-37; Esler, "Judean Ethnic Identity in Josephus," 73-91; McInerney, Companion to Ethnicity in the Ancient Mediterranean.

2 See, e.g., Imhoff and Kaell, "Lineage Matters," 95-127; Weitzman, The Origin of the Jews, 274-316. 
procreation and parturition. ${ }^{3}$ Genealogy occupies an ambiguous place in these debates, depending on whether people assign it a biological dimension or not. As a matter of fact, genealogy is not merely a biological notion, at least in societies where adoption is practiced. Genealogies may include adoptive parents and adopted descendants, which highlights the conceptual difference between genealogy and blood ties. However, not all societies are open to the notion of adoption; particularly significant for this $J A J$ issue is the fact that adoption exists neither in biblical law nor in rabbinic law. Despite this reservation, it is safe to assume that genealogies, especially when they relate to distant ancestors, are in many ways cultural constructions.

Beyond their uses in individual and ethnic self-definitions, genealogies play a role in defining social groups and consolidating social hierarchies and power relationships. In Antiquity as in later contexts, monarchy, aristocracy, and priesthood were generally related to lineage. Moreover, in the Hellenistic and Roman worlds, women's lineage mattered too (especially in civic and aristocratic contexts). For both men and women, a prestigious ancestry heightened the expectations concerning the spouse's pedigree. ${ }^{4}$ Genealogy was thus influential in establishing alliances between groups, in constructing networks, and in securing power.

Yet power was not based solely on pedigree. In the Hellenistic world, the Diadochi initially faced a lack of political legitimacy because they were not Alexander the Great's relatives and did not belong to the family that had traditionally reigned over Macedonia. They compensated for this lack with their merit, which consisted at least in part of their military capacity. Very quickly, however, they reintroduced the dynastic principle, as Benedikt Eckhardt notes in his article "The Impact of Hellenistic Monarchy on Jewish Identity" in this issue. Eckhardt further remarks that the same pattern can be observed in the case of the Hasmoneans: they were initially wanting in lineage - for they were not Oniads - and argued for a legitimacy based on military victories and

3 See, e.g., Schneider, A Critique of the Study of Kinship, which rejects the notion that kinship has to do with reproduction; Read, "What Is Kinship?," 78-117. Warren Shapiro has sharply criticized the "new kinship studies" associated with Schneider and others, arguing that models of procreation are much more universal than these scholars are ready to admit ("What Human Kinship Is Primarily About," 137-53). Conversely, the collective volume edited by Bamford and Leach, Kinship and Beyond, explores "how genealogical thinking permeates a range of social institutions such as property inheritance, pedagogy, ethnicity, class and politics, not to mention how we conceptualize human ecology," therefore going well beyond the issue of genealogy or procreation as the basis of kinship (13).

4 As the articles of both Yael Wilfand and Yedidah Koren in this issue show, genealogy also played a role in rabbinic marital laws, and the rabbis' concern about some Jews' problematic lineage was strongly connected to the regulation of marriages. 
faithfulness to the Law, which 1 Maccabees presents as reflecting their divine election. Yet beginning with Simon they also reestablished dynastic succession as the core principle of political legitimacy.

In a Roman context, the discourse of the elites emphasized both ancestry and merit. ${ }^{5}$ Cicero, the homo novus par excellence, perfectly illustrates in his writings how a prestigious pedigree was expected to be accompanied by personal valor, while a "new man" who served the Republic well could give his descendants access to nobility. With the Principate, the dynastic principle became central to Rome's political system, even though the designation of the Princeps was theoretically subject to the Senate's approval. Yet this dynastic principle was in no way absolute. In contrast to the Hellenistic kings, the JulioClaudians (and later emperors) resorted to adoption in order to simultaneously bypass and maintain the genealogical principle. Under the Julio-Claudians, merit was not the main criterion in the choice of adoptee, as family connections remained a crucial factor. In the long run, however, merit in the sense of military valor and the ability to win the legions' support played a central role in the accession to power of several emperors. Again, what started as a form of election was often followed by the designation of a successor among the emperor's male descendants, resulting in the reaffirmation of the genealogical and dynastic principle. But the example of the Tetrarchy under Diocletian shows that yet other models of transmission of imperial power were possible. In short, the role played by genealogy in gaining and consolidating power varied and was never absolute.

As far as ancient Israel is concerned, it is clear that genealogical thinking pervades biblical texts, relating to both the definition of the elites (Davidic lineage for kings, Aaronide descent for priests) and that of the people at large. The Hebrew Bible nevertheless contains at least two models for defining Israel, which we may roughly characterize as "genealogical" and "covenantal" (or "Sinaitic"). ${ }^{6}$ First, "Israel" designates the descendants of Abraham via Isaac and

5 See my article in this issue.

6 On the respective roles of genealogy and commitment to the Torah in the definition of Israel, see Porton, The Stranger within Your Gates; Stern, Jewish Identity in Early Rabbinic Writings, 90-95; Cohen, Beginnings of Jewishness, esp. 308-40; Levinson, "Bodies and Bo(a)rders," 34445; Hayes, Gentile Impurities and Jewish Identities, 164-92; Collins, The Invention of Judaism, $5^{-8}$. According to Joshua Levinson, this dual definition emerged only after $70 \mathrm{CE}$. Prior to the destruction of the Second Temple, there were "various and conflicting models of identity (covenantal, biological, historical, territorial, tribal)" ("Bodies and Bo(a)rders," 344). However, these categories overlap to a great extent, especially when they are considered from an emic perspective. Moreover, while history and territory may represent important aspects of identity, they do not in themselves constitute ways to integrate non-Jews into Israel independent of the acceptance of the commandments. I therefore contend that as far as the integration of 
Jacob: in Genesis and at the beginning of the book of Exodus, the members of Israel are beney Israel, a family or a clan, bound together by common ancestors and kinship ties. Second, in relation to the Exodus and the Revelation of the Torah at Sinai, another definition of Israel emerges, based on the acceptance of the Sinaitic covenant and not merely on descent. Non-Israelites may be included in the covenant between God and Israel on the basis of their willingness to observe God's commandments, despite their non-Israelite lineage. According to Deut 29:9-12, they belong to the people ('am), even though at the individual level they do not become beney Israel.

In the long run, this openness to non-Israelites led, in a Greco-Roman cultural context, to the emergence of the notion that a non-Jew could become a Jew. However, some Jewish sources testify to a rejection of this idea and to a strong commitment to the genealogical principle. ${ }^{7}$ Moreover, even within sources that show acceptance of "conversion," lineage often continues to play an important role and to create hierarchies within Israel, be it between native Jews and converts or between priests, Levites, Israelites and other categories, such as mamzerim or freed slaves. As a matter of fact, the Hebrew Bible already displays a tension between the idea of Israel as an egalitarian society and the descent-based hierarchy among priests, Levites, and Israelites. In Second Temple and rabbinic texts, these subdivisions are sometimes refined further, as when a specific group of priests is singled out or a new category - such as freed slaves - is created. ${ }^{8}$

Yet some ancient texts also challenged genealogical dividing lines, both those between Jews and non-Jews and those between the different groups within Israel. Virtue, merit, or righteousness could blur these lines in some cases. A passage of the Mishnah that ranks Jews according to their lineage affirms that a mamzer who is a disciple of the sages is greater than a high priest who is 'am ha-aretz (ignorant of the Torah) (m. Horayot 3:8). Here the genealogical hierarchy appears to be subordinated to a hierarchy based on Torah knowledge. Alternatively, a passage from the Mekhilta de-Arayot in Sifra claims that a righteous Gentile who observes the Torah (i.e., a convert) is equal to a high priest. ${ }^{9}$ From a moral and religious perspective, the value of Torah knowledge

foreigners is concerned, the dual paradigm (descent or acceptance of the commandments) is already present in biblical texts.

7 See, e.g., Himmelfarb, A Kingdom of Priests, 53-84 (on Jubilees); Thiessen, Contesting Conversion: Genealogy.

8 On freed slaves, see Hezser, Jewish Slavery in Antiquity; Dohrmann, "Manumission and Transformation," 51-65; Wilfand, "Roman Treatment of Freedwomen."

9 Sifra, Aharey Mot 9.13.13, ed. Weiss, 86b (on Leviticus 18:5). On this passage, see Hirshman, Torah for the Entire World, 45-6o; idem, "Rabbinic Universalism," 107-10. In contrast to 
and practice may thus erase genealogical distinctions. However, whether it erases the halakhic consequences of these distinctions is a different question.

The articles gathered in this thematic issue explore the dynamics of genealogy and merit in Jewish texts from the Hellenistic and Roman periods, in relation to individual, family, and ethnic self-definitions, as well as individual and group strategies meant to establish legitimacy, prestige, or control over other segments of society. (Such groups may consist, for example, of a priestly clan or a rabbinic network.)

First, Benedikt Eckhardt looks at how the criteria for membership in the people of Israel underwent significant transformations in Hellenistic Judea and how the notion of "conversion" subsequently developed. He challenges previous analyses of Hellenism's impact on Judean society - including Shaye Cohen's theory about the influence of the politeia model on the Hasmoneans but observes that the deposing of the Oniads and the rise of a new dynasty of high priests were to a great extent the results of Seleucid royal decisions. Hasmonean rule called into question the value of genealogy as an ordering principle, at least originally. Furthermore, Eckhardt argues that this relativization of genealogy had a lasting impact not only on the political sphere, as far as the definition of the ruling elites was concerned, but also on Judean society more widely, leading to the redefinition of Jewishness as an "elective identity."

My article similarly discusses both criteria for membership in the priestly elite and those for integration into the people of Israel, but in the Roman period and from Josephus' perspective. It assesses the importance of both lineage and virtue in Josephus' views of the Jewish nobility and the Jewish people. Furthermore, I investigate the roles of Josephus' priestly education and exposure to Roman culture in his reflections on these topics. In contrast to Eckhardt's conclusion concerning Hellenistic Judea - that the criteria for belonging underwent a parallel transformation in the case of the ruling group and that of Judean society at large - I argue that Josephus' view of membership in the elite remained fundamentally grounded in genealogy and thus differed from his notion of membership in the people of Israel, which was based not on birth alone but also on individual choice. From Josephus' perspective, the fact that non-Jews chose to join the Jewish people was a demonstration of the superiority of the Mosaic law - and of the virtuous character of converts, whose merit compensated for their non-Israelite lineage.

Hirshman, who claims that this passage speaks about a Gentile who does not convert, I contend that it deals with a convert (see my forthcoming book Jews and Their Roman Rivals, Chapter 4). 
While these two papers tackle the social and political relevance of genealogy (social and political legitimacy, integration into a community), the following article, by Yael Wilfand, examines both the integration of outsiders into the Jewish community and the relevance of genealogy from the perspective of kinship (as far as marriages are concerned). Looking at rabbinic literature from the Land of Israel, Wilfand investigates the integration of the descendants of gerim (converts) into the Jewish people, focusing on two issues in particular: the eligibility of converts' daughters for marriage with priests, and the permission for children of converts to recite certain blessings. She emphasizes the importance of the Roman context in which these rabbinic works were produced, arguing that the Roman model of citizenship and Roman norms concerning freed slaves influenced rabbinic views of converts and their descendants and, in the long run, enabled the acceptance of the converts' descendants as full members of Israel.

Yedidah Koren's contribution too explores the importance of genealogy in rabbinic literature from the perspective of kinship. Yet this time the focus is not on the descendants of converts but on the category of pesulim, Jews who are unfit to marry other Jews because of their problematic pedigree (the most wellknown case in this category being the mamzer). Koren's argument unfolds in two directions. First, she challenges the common assumption that Palestinian rabbinic sources display more leniency than Babylonian ones toward the maintenance of pedigree and the transmission of genealogical information, showing that both early and late Palestinian sages were concerned about the publication of genealogical knowledge and supported exposing mamzerim. Second, she argues that, contrary to another common scholarly view, most rabbinic sources do not assume that the rabbis possessed genealogical knowledge (which does not mean that lineage was not important to the rabbis). Rather, such knowledge appears to have been a wider social issue involving many different actors, including women. According to many rabbinic sources, lineage mattered to Jewish communities at large and not merely to rabbis.

In contrast to Koren, Moshe Lavee claims that the characterization of Babylonian rabbinic literature as more anxious about genealogical matters than its Palestinian counterpart holds firm. He suggests that rabbinic approaches to genealogy should be seen as part of holistic and coherent social systems, in which ideas about genealogy, patriarchal authority, and marriage were interrelated. Based on a few examples from midrashim (including a lost midrash retrieved from the Cairo Genizah) and the Babylonian Talmud, Lavee argues that Palestinian rabbinic views of genealogy and kinship tend to conform to what Guichard and Goody define as the "Occidental," bi-lineal family model, while Babylonian views are closer to the "Oriental" model, characterized by 
patrilinearity and a greater importance attributed to genealogy, among other things. Lavee thus shows how different types of family constructions and social systems correlate with different levels of emphasis on genealogy.

Finally, the question of the rabbis' interest in pedigree and genealogical information is also present in Geoffrey Herman's article, with which we return to the sociopolitical dimension of genealogy. Herman's contribution pertains to priests and rabbis in Sasanian Babylonia, two groups often viewed as rivals. A common scholarly assumption is that while priests are defined by their lineage, rabbis defend an alternative model, in which Torah study and intellectual qualities prevail over birth. Herman shows that in Sasanian Babylonia, the situation was more complex: not only is there evidence of a positive and respectful attitude toward the priesthood among Babylonian rabbis, but some rabbinic passages put forward the pedigreed Torah scholar as the ideal type of leader, and this pedigree is generally a priestly one.

As on so many other topics, rabbinic literature does not speak with one voice. Rabbis held different opinions on the roles of genealogy and merit, concerning both the integration of non-Jews into the Jewish people and individual statuses within Israel. This collection of articles limits its focus to Jewish texts from Antiquity (up to the beginning of the Middle Ages), yet it is clear that Jewish thinkers, jurists, and Jewish communities at large have continued to debate these issues throughout the ages, up to our time.10

\section{Bibliography}

Bamford, Sandra, and James Leach, eds. Kinship and Beyond: The Genealogical Model Reconsidered. New York: Berghahn Books, 2009.

Berthelot, Katell. Jews and Their Roman Rivals. Forthcoming at Princeton University Press.

Cohen, Shaye J. D. The Beginnings of Jewishness: Boundaries, Varieties, Uncertainties. Hellenistic Culture and Society 3. Berkeley: University of California Press, 1999.

Collins, John J. The Invention of Judaism: Torah and Jewish Identity from Deuteronomy to Paul. Oakland: University of California Press, 2017.

10 Acknowledgements: This thematic issue stems from a panel held at the congress of the European Association of Jewish Studies that took place in Krakow in July 2018. The participants' costs were partly covered by the ERC project JUDAISM AND ROME, under the European Union's Seventh Framework Program (FP/2007-2013)/ERC Grant Agreement no. 614 424. The project has been managed under the auspices of the Centre national de la recherche scientifique (CNRS) and Aix-Marseille University, UMR 7297 TDMAM (Aix-enProvence, France). 
Dohrmann, Natalie B. "Manumission and Transformation in Jewish and Roman Law." Pages 51-65 in Jewish Biblical Interpretation and Cultural Exchange: Comparative Exegesis in Context. Edited by Natalie B. Dohrmann and David Stern. Philadelphia: University of Pennsylvania Press, 2008.

Esler, Philip F. “Judean Ethnic Identity in Josephus' Against Apion." Pages 73-91 in A Wandering Galilean: Essays in Honour of Seán Freyne. Edited by Zuleika Rodgers et al. Leiden: Brill, 2009 .

Hayes, Christine E. Gentile Impurities and Jewish Identities: Intermarriage and Conversion from the Bible to the Talmud. Oxford: Oxford University Press, 2002.

Hezser, Catherine. Jewish Slavery in Antiquity. Oxford: Oxford University Press, 2005.

Himmelfarb, Martha. A Kingdom of Priests: Ancestry and Merit in Ancient Judaism. Philadelphia: University of Pennsylvania Press, 2006.

Hirshman, Menahem. Torah for the Entire World. Tel Aviv: Ha-Kibbutz ha-Mehuhad, 1999. (Hebrew)

Hirshman, Menahem. "Rabbinic Universalism in the Second and Third Centuries." HTR 93.2 (2000): 101-15.

Hutchinson, John, and Anthony D. Smith, eds. Ethnicity. Oxford: Oxford University Press, 1996.

Imhoff, Sarah, and Hillary Kaell. "Lineage Matters: DNA, Race, and Gene Talk in Judaism and Messianic Judaism." Religion and American Culture: A Journal of Interpretation 27.1 (2017): 95-127.

Levinson, Joshua. "Bodies and Bo(a)rders: Emerging Fictions of Identity in Late Antiquity." HTR 93.4 (2000): 343-72.

Malkin, I., and C. Müller. "Vingt ans d'ethnicité: bilan historiographique et application du concept aux études anciennes." Pages 25-37 in Mobilités grecques. Mouvements, réseaux, contacts en Méditerranée, de l'époque archaïque à l'époque hellénistique. Edited by Laurent Capdetrey and Julien Zurbach. Bordeaux: Ausonius, 2012.

McInerney, Jeremy, ed. A Companion to Ethnicity in the Ancient Mediterranean. Chichester: Wiley Blackwell, 2014.

Porton, Gary G. The Stranger within Your Gates: Converts and Conversions in Rabbinic Literature. Chicago: University of Chicago Press, 1994.

Read, Dwight. "What Is Kinship?" Pages 78-117 in The Cultural Analysis of Kinship: The Legacy of David Schneider and Its Implications for Anthropological Relativism. Edited by Richard Feinberg and Martin Ottenheimer. Urbana: University of Illinois Press, 2001.

Schneider, David M. A Critique of the Study of Kinship. Ann Arbor: University of Michigan, 1984.

Shapiro, Warren. "What Human Kinship Is Primarily About: Toward a Critique of the New Kinship Studies." Social Anthropology/Anthropologie Sociale 16.2 (2008): $137-53$. 
Stern, Sacha. Jewish Identity in Early Rabbinic Writings. Leiden: Brill, 1994.

Thiessen, Matthew. Contesting Conversion: Genealogy, Circumcision, and Identity in Ancient Judaism and Christianity. Oxford: Oxford University Press, 2011.

Weitzman, Steven. The Origin of the Jews: The Quest for Roots in a Rootless Age. Princeton: Princeton University Press, 2017.

Wilfand, Yael. "Did Roman Treatment of Freedwomen Influence Rabbinic Halakhah on the Status of Female Converts in Marriage?" The Journal of Legal History 40 (2019): 182-202. https://doi.org/10.1080/01440365.2019.1625216. Published online: 11 June 2019 . 